\title{
Lily Robert-Foley
}

\section{Femalentendue}

\begin{abstract}
This fictocritical experiment, self-translated between English and French, attempts a Slash fiction of Joanna Russ's 1975 work of feminist science fiction The Female Man (Russ 2011 [1975]). In Russ's book, characters travel in between possible worlds, encountering possible versions of themselves that are created each time an infinitesimal decision or change happens. In this work I propose that translation opens possible worlds in language in much the same way that decisions and changes do in-between Russ's universes. I therefore propose an nth world existing in-between languages that I call [xxx]. This world [xxx] is not to be found in one version of this text nor in the other but in the space opened in-between my two translations.

Keywords: fictocriticism, self-translation, feminist science fiction
\end{abstract}

Sometimes you bend down to tie your shoe, and then you either tie your shoe or you don't; you either straighten up instantly or you don't. Every choice begets at least two worlds of possibility, that is, one in which you do and one in which you don't; or very likely many more... To carry this line of argument further, there must be an infinite number of possible universes... Every displacement of every molecule, every change in orbit of every electron, every quantum of light that strikes here and not there - each of these must somewhere have its alternative. It's possible too, that there is no such thing as one clear line or strand of probability, and that we live on a sort of twisted braid, blurring from one to the other without even
Lorsque, parfois, vous vous penchez pour lacer votre chaussure, vous pouvez soit la lacer, soit ne pas la lacer; peut-être vous relevez-vous aussitôt, ou peut-être pas. Chaque choix engendre au moins deux ensembles de probabilités; un dans lequel vous accomplissez telle chose, et un dans lequel vous ne l'accomplissez pas; et généralement beaucoup plus... Si l'on développe ce raisonnement, il doit y avoir un nombre infini d'univers possibles... Chaque déplacement d'une molécule, chaque changement d'orbite de quelque électron que ce soit, chaque quantum de lumière qui frappe ici et pas là - chacun doit correspondre, quelque part, à une autre éventualité. Il est également possible qu'il n'y ait pas de ligne précise ni de 
knowing it.

(Joanna Russ, The Female

Man [1975])

In Joanna Russ' The Female Man

(1975), a scientist from a world

called Whileaway discovers

probability mechanics and figures

out how to travel between possible

universes, to jump from one

probability strand to another. On

Whileaway, the male part of the

human species was wiped out by a

plague that began in PC 17

(Preceding Catastrophe) and ended

in AC 03. Since this time, females

solely inhabit Whileway. In the

distant future, Janet Evason (a

translation of her name, as she

explains in a TV interview: "Evason

is not "son" but "daughter." This is

your translation' (17)), is sent

because she can be 'spared' (21), to

an alternative universe in which

women and men are separated in

two. In The Female Man, we

encounter over two alternative

universes, of varying differences

from our own and from each other.

In this article I would like to present two universes, I mean, two languages. Sometimes I think I should know all languages. I should, but it doesn't mean that the inbetween space between two languages is not also multiple and luminous, creating perhaps not other languages but other texts, far beyond the scope of one text plus another. A text and its translation are far more than one, or even two texts, and open into a space that is neither empty nor neutral. For, languages are universes, and universes are not neutral - at least not the ones created by Russ, where different universes are organized around different principles of distinguishing gender. Gender begets, or engenders ('engendre') in the above citation: in French, suite de probabilités, et que nous vivions dans une sorte de tresse entortillée, glissante, puisque nous restons dans les limites d'un ensemble de variations qui pour nous ne font aucune différence.

(Joanna Russ, The Female

Man, trans Henry-Luc

Planchat, L'autre Moitié de

l'Homme [1977])

Dans L'Autre Moitié de l'Homme de Joanna Russ (trans 1977, Henry-Luc Planchat), une scientifique qui vient d'une terre appelée 'Lointemps', invente une mécanique quantique de probabilité qui permet de voyager entre les univers, et découvre ainsi une manière de sauter entre les fils ou les mèches ou les brins ou les branches ou les courants de probabilités. Sur Lointemps, la partie «mâle» de l'espèce humaine fût anéantie par une peste, qui débuta en 17 PC (Précédant la Catastrophe) et se finit en 03 AC. Depuis lors, Lointemps est peuplée uniquement de femmes. Dans un avenir lointain, Janet Evason (une traduction qui a été faite de son nom, comme elle l'explique dans un entretien à la télévision «JE: Evason ne signifie pas 'fils' mais 'fille' d'Eva. Eva-son c'est votre traduction.» (34)) est envoyée dans un univers où les mâles et les femelles sont divisés en deux catégories, «[p]arce qu'on peut se passer de moi» (39). Dans

L'Autre Moitié de l'Homme, deux autres univers alternatifs sont présentés, qui sont plus ou moins similaires aux nôtres, et également l'un à l'autre.

Dans cet article je voudrais déjà vous présenter deux univers, je veux dire, deux langues: le français et l'anglais. Parfois je me dis que cela serait bien de pouvoir connaître toutes les langues. C'est vrai, mais cela n'empêche pas que l'entre-deux de deux langues fait beaucoup plus que $1+1$, car l'espace de négociation, de conflit, donc en gros, d'amitié entre deux langues, n'est ni vide ni neutre. Car, les langues sont les mondes, et 
begetting is assumed to be an affair of gender, or engendering - which, as we shall see is not the case on Whileaway (where technology has enabled women to 'beget' other women with each other). This has an immediate effect on the 'world', an 'ensemble' in French, which also means 'together' (like a reproductive couple?). But this engendering codes for other 'alternatives' or 'autres éventualités'. But how destined or finite are these 'alternatives' or 'autres éventualités'? Already, their destinies are not the same even in the very meanings of the words, 'blurred', 'glissante' (slippery), the forking paths of gender lead off in many directions, some towards ends ('éventualités'), like the end of a book, and others towards... who knows? Can another gender structure engender an alternative ending?

A translator thus creates another 'end' for the possible alternatives for a given work, like Russ's, and they live there. However, if I happen to bump into Henry-Luc Planchat, that translator of Russ's Female Man, I have a feeling this encounter would create another universe again all together, as I would translate his title back into English for him: 'The other half of man', and try to explain to him that the title of The Female Man, does not carry the same implication that a woman is forever destined ('éventualité') to inhabit a universe in which she is man's 'other'.

In another one of these universes lives the author of The Female Man (deceased in 2011). You might be tempted to identify this one, or another universe in The Female Man, to our own, because of the several striking resemblances. Do not be fooled! According to the theory of probability mechanics, no two universes can be entirely the same.

In Russ's fiction, universes are composed of and differentiated from one another by quantized molecules: 'Our universe is quantized; therefore the differences between possible les mondes ne sont pas neutres $-\mathrm{du}$ moins ils ne le sont pas lorsqu'il s'agit des mondes de Russ, où c'est le propre de chacun d'organiser les rapports de genre différemment. Dans un premier temps, dans la traduction du titre - en anglais The Female Man -, une ambiguïté existe dans la syntaxe anglaise où le mot «Female» fonctionne à la fois comme adjectif qui caractérise le nom (comme «female bear»), mais également, comme nom composé (comme «desk lamp»). Le traducteur - un homme - traduit à travers sa propre perspective, c'est-à-dire, sa position de «soi» pour qui la femme est «autre». Susanne de LotbinièreHarwood, nous donna en 1991 la notion de la traduction féministe, avec une traductrice féministe qui, allant ainsi à l'encontre de la maxime de l'invisibilité du traducteur, s'inclura dans un texte misogyne en utilisant sa propre voix pour le transformer et le ramener à son sens. En 1977, Henry LucPlanchat nous offrait la traduction masculiniste. Cet exemple démontre bien que ni le féminisme et le masculinisme, ni les langues, ne sont équivalents dans une lutte où $1=1$.

Le traducteur (né en 1953), en traduisant donc, crée un «autre» dans la série des univers possibles inventés dans l'ouvrage de Russ, et il 1'habite. Si vous croisez Henry-Luc Planchat à son bureau en train d'éditer son fanzine L'Aube enclavée, ou à traduire un(e) des auteur(e)s les plus connu(e)s de la science-fiction anglo-saxonne, tel que Le Guin, Dick ou Delaney, ou encore à rédiger le mode d'emploi d'une imprimante (Turbo Pascal 4.0, Paris, Eyrolles, 1989) - ne soyez pas tentée de croire qu'il s'agit du même monde existant dans le livre en anglais de Russ.

L'auteure (née en 1937) aussi habite un de ces univers inventés dans le livre. Vous-même serez peut-être également tentée d'assimiler son univers, ou un autre, à l'un de nos univers (le monde qui existe au moment où j'écris, ou celui qui 
universes (although very small) must be similarly quantized, and the number of such universes must be finite (although very large)' (154). She tells of several juxtaposed universes. One is that of the male/female universe, another that of the female universe or the female/female universe, another the universe of the author, and a fourth in which men and women are engaged in an interminable war. Since these universes are 'finite (although very large)', it is not a far leap to imagine another one, which is what I will undertake in this article: a Slash fiction of Russ's book [1].

I wonder then, how to begin building this Slash universe. What would it look like? How would it function? How might families form, identities coalesce, economies, governments, markets, work places, play, art, belief systems, be constructed? What is the relationship to nature? In what way might this universe be inhabited? Is it inhabitable? What is it made of and how would I get there - or perhaps I am already there?

Translating is never neutral. It is the act of a subject at work within a specific socialpolitical context. The $I$ which translates inscribes her knowledge, her choices, her intentions and her convictions into the text she is rewriting. Translation can thus be a veritable political tool. Indeed, in the passage from departure to arrival language, it is possible to make appear or disappear, a word or a world. (LotbinièreHarwood 1991: 27, my translation)

One way to think about this is to start from our present universe, which happens to be made from language. This behooves us to change the unit existe au moment où vous me lisez) - mais ne tombez pas dans le piège ! Dans la science de Russ, il est impossible de voyager en avant ou en arrière sur le même fil ou mèche ou brin ou branche ou courant de probabilité.

Dans la fiction de Russ, les univers sont composés des molécules quantifiées. C'est ainsi qu'un univers se distingue de tous les autres. «Notre univers est quantifié; donc les différences entre les univers possibles (bien que très petites) doivent être quantifiées de la même façon, et le nombre de ces univers doit être fini (bien que très élevé)» (217). Russ élabore plusieurs univers juxtaposés, dont l'un est divisé entre mâle et femelle; un autre, un peu moins divisé, entre femelle/femelle; un autre, celui de l'auteure; et un dernier dans lequel les hommes et les femmes sont enfermés dans une guerre perpétuelle. Puisque ces univers sont presque finis («le nombre... fini bien que très élevé»), il ne faut pas divaguer très loin pour en imaginer un autre: celui que je vais entreprendre de réaliser dans cet article. Une fiction Slash du livre de Russ [1].

Je me demande alors comment entamer la construction de cet univers Slash. A quoi ressembleraitil ? Comment fonctionnerait-il, ou elle ? Comment et de quoi seraient constitués les familles, les identités, l'architecture, le transport, la nourriture, les déchets, les convention sociales, le système judiciaire et pénale, la musique, les jardins, le sexe? De quoi est-il fait? De quelle matière? Est-il rond, carré, triangulaire, ou d'une nouvelle forme impensable? Peut-être même que j’y suis déjà allée?

Traduire n'est jamais neutre. C'est l'acte d'une subjectivité à l'œuvre dans un contexte socio-politique précis. Le je qui traduit, 
of measure: instead of molecules, this universe uses the stuff of language: signifiers and signifieds, phonemes, graphemes, morephemes, lexemes, sememes, ink, paper, sound, code.

Languages are already like molecules in a way insofar as each instance of a language, each utterance, each book, each letter written on a scrap of paper, each linguistic unit thought or dreamed of, changes its language imperceptibly, branching off into a new probability strand, creating a new universe. I would remind you that in the history of thinking on translation, language is a substance, and has matter. In Dryden (1680), language in translation is a fluid, spilling from one vessel to another, or blood transfused between bodies. In Humboldt (1816), it is like water, changing form to make the clouds in the sky. In Schleiermacher (1813), learning to think in a foreign language is like the synthesizing of natural materials to form new chemical compounds. Language, or languages then, involve the same elements that make up bodies, plants and animals, the earth and the stars.

Recent work on gender and translation likewise proposes thinking the text as a body, as in Aarón Lacayo's article on queer and embodied poetics: 'In the act of translation, texts engage with each other as bodies, enacting a corporeal encounter marked by both a proximity and a distance' (Lacayo 2014: 217). In Lacayo, translation gives us queer because it dismantles the binary structure of the meeting between two: '[translation] is a queer encounter to the extent that it is not a difference between male and female but always a difference between a bodily text and an infinite number of unknowns yet to come' (219). Here, Lacayo is obviously making reference to the uncountable and inscrit son savoir, ses choix, ses intentions, ses convictions, dans le texte qui se réécrit. En effet il est possible, au moment du passage de la langue de départ à la langue d'arrivée, de faire apparaître ou disparaître un mot ou un monde. (Lotbinière-Harwood 1991: 27)

Une manière d'envisager cela serait de commencer dans notre univers ciprésent, qui se trouve être fait de matière langagière. Il convient alors de changer l'unité de mesure: au lieu des molécules, ce nouvel univers emploierait des mécanismes, organes et transmetteurs de la langue: signifiants et signifiés, phonèmes, graphèmes, morphèmes, lexèmes, sémèmes, du papier, des bouches, des oreilles, les bandes de son, les écrans.

Attardons-nous donc un instant sur... sur... la langue? Ou est-ce le langage? Comment écrire en français ce mot «language»? A chaque fois que j'hésite, la matière des langues, les molécules qui constituent les différents langages, se divisent en univers alternatifs. De nouveaux univers. Rappelons que dans l'histoire de la pensée de la traduction, la langue ou le langage sont matériels; c'est-à-dire qu'elles ont de la matière. Chez Dryden (1680), la langue ou le langage sont fluides, versés d'un récipient à un autre, ou encore, semblable à du sang transfusé d'un corps à un autre. Chez Humboldt (1816), la langue ou le langage sont comme de l'eau, qui se transforme pour former les nuages dans le ciel. Chez Schleiermacher (1813), apprendre à penser dans une langue étrangère est semblable au processus chimique de synthétisation de la matière brute. La langue ou le langage sont donc faits des mêmes composants que les corps, les plantes, les animaux, la terre, et les étoiles. 
blurred unraveling of potentialities

engendered in the practice of

translation, in which possible universes erupt like a film of the

Spring in fast forward.

Whileawayan probability mechanics are fairly precise, and travel is accomplished normally through 'access points' (91) in possible universes. The precision of travel depends upon being able to 'distinguish the very smallest differences - say, that of one quantum of light - for otherwise we could not find our way to the same universe time after time, nor could we return to our own' (154). In other words, if translation is possible, language must be 'quantized' much the same way that Russ's universes are. However there is this matter of travel between universes, of the space between, the 'what-do-youcall-it' (91) or the 'great, gray mighthave-been' (153). What lies there?

We cannot know for sure, and new previously undetectable worlds are being discovered all the time, which explains why travellers from other possible universes have not contacted us. Whileawayans are not the only ones with this technology, not to mention that they are notoriously discrete. They also have no desire for conquest or domination of other worlds, or to steal knowledge from them. (To quote a famous Whileawayan explorer when 'asked what she expected to find in space, Betty Murano made the immortal quip, 'Nothing', (12).) But there are other worlds, such as the one inhabited by Alice Jael, an employee of the Bureau of Comparative Ethnology who appears in Part 9 out of the 'matron blackness' (151), searching for her own future by hunting down versions of herself in other universes. She would no doubt have liked to find the version of herself living in one of

Les réflexions actuelles consacrées à l'intersection du genre et de la traduction, proposent également de penser le texte comme un corps, comme l'a récemment fait Aarón Lacayo dans un article sur la poétique d'une corporalité queer: «Dans l'acte de traduire, les textes entrent en contact comme les corps, et jouent donc une rencontre corporelle marquée à la fois par une proximité et par une distance» (Lacayo 2014: 217, ma traduction). Chez Lacayo, la traduction nous donne le queer parce qu'elle fait jaillir l'entre-deux de la structure binaire : «la traduction est une rencontre queer dans la mesure où il n'est pas question de la différence entre la femelle et le mâle, mais toujours question de la différence entre un texte corporel et un nombre infini d'inconnus à venir» (219, ma traduction). Ici, Lacayo fait clairement référence au chevauchement des potentialités innombrables et floues que la pratique de la traduction déclenche, et d'où les univers possibles surgissent comme votre maison s'effondre, détruite avant même que vous réalisiez ce qui se passe.

La mécanique de probabilité de Lointemps est assez rigoureuse. Les voyages se font à travers les «points de débarquement» (130) dans les univers possibles. Voyager avec précision consiste à «être capables de distinguer des différences infimes - disons, de l'ordre d'un quantum de lumière - car autrement nous ne pourrions pas retrouver le chemin d'un même univers, ni retourner dans le nôtre» (217). Autrement dit, si la traduction est bien possible, la langue ou le langage doivent être «quantifié[s]», de façon plus ou moins similaire à celle de l'univers de Russ. Il y a pourtant l'affaire du voyage entre les univers, de l'espace entre, les «machin[s]» (91), ou «les brouillards du grand possible» (215). Qu'est-ce qui gît donc là ? 
our worlds (the world that exists at the moment I write this or the one that exists as you read it). She comments on Whileawayan stealth, 'You, Janet, were almost impossible to find. The universe in which your Earth exists does not even register on our instruments; neither do those for quite a probable spread on either side of you' (154).

The technology I am dealing with (the technology of translation) is not quite as precise (quantized) as Whileawayan or technologies from other worlds are (the unnamed world of Alice Jael for instance). The materials are slippery, their molecules moving too rapidly to measure, shifting out of its perceived state at the moment of perception: to translate is to change. The machine, although massive and ancient, has many parts, and those parts do not always work in harmony with others. I suspect that I may not be the only one using it, since when parts break (more often than not) I go in search of a part to replace it, and when I return, the part has already been replaced by something else, and my part no longer fits. Nevertheless, it seems to work more or less, which never ceases to astound me.

The technology in Russ's universes functions with the use of an 'induction helmet' (13) - rather than a machine, which perhaps is why it seems to work more smoothly than in mine. I would love to get my hands on one, but for that I would have to get to Whileaway. Perhaps indeed, I have to get to Whileaway before I can get to my as yet unnamed Slash universe. For the time being however, my machine is not capable of matching destination access point coordinates to arrival
Nous l'ignorons assurément, et de nouveaux mondes, préalablement inconnus, sont sans cesse découverts, ce qui explique pourquoi les voyageurs des autres univers possibles ne nous ont pas encore contactés. Les gens de Lointemps ne sont pas les seuls à posséder cette technologie, sans pour autant parler du fait qu'elles sont notoirement discrètes. Elles n'ont pas non plus le désir de conquérir ou de dominer les autres mondes, ni de dérober leurs connaissances. (Pour citer une exploratrice célèbre de Lointemps, "Quand on lui demanda ce qu'elle pensait trouver dans l'espace, Betty Murano eut cette immortelle répartie: 'Rien du tout.'» (27)). Mais il existe d'autres mondes, tel que celui habité par Alice Jael, une employée du Bureau d'Ethnologie Comparée qui apparaît à la neuvième partie de la «matrone noire» (214), et qui cherche à connaître son propre avenir en récupérant les autres versions d'elle-même dans d'autres univers. Elle aurait sans doute aimé trouver la version d'elle-même qui habite dans un de nos mondes. Alice Jael remarque la discrétion des gens de Lointemps: «Vous, Janet, vous étiez presque impossible à découvrir. L'univers dans lequel se trouve votre Terre n'existe même pas sur nos registres et n'est pas capté par nos instruments; non plus que ceux qui sont proches de votre univers» (218).

La technologie à laquelle j'ai accès (la technologie de la traduction) n'est pas tout à fait aussi précise (quantifiée) que celle de Lointemps, ou des technologies des autres mondes (celui sans nom d'Alice Jael par exemple). D'abord, la matière est insaisissable, les molécules se déplacent trop rapidement pour être mesurées, ses localisations meuvent au moment d'être localisées: traduire c'est changer. Le machin, quoique massif et ancien, a beaucoup de pièces, et ses pièces ne fonctionnent pas toujours en harmonie les unes avec les autres. Je me doute, parfois, que je ne suis pas la seule à l'utiliser. 
coordinates. I always end up somewhere I did not intend.

I calculated the coordinates by taking the queer root of my current space time coordinates and multiplying them by the sum of all known languages. But perhaps because these are both approximate or incalculable (and always changing), after inputting my 'numbers' into the machine, it was at first as Russ describes it, your current surroundings going 'in and out of existence forty-thousand times a second' (21), but rather than something new materializing in front of my eyes, I found myself tangled up in a very heavy, dense fabric - a royal robe of sorts. This fabric constricted very much the movement of my limbs, so that I was as a drowning person, flailing about trying to break free to the surface. I knew that this indiscriminate thrashing was probably not helping me escape, but my desire to do so was such that I couldn't help myself.

I finally did escape, after much thrashing, and disentangled myself from the folds. I could hardly believe what I saw before me: two spirals of floating embryos stretching out beyond the limits of my vision. 'This representing of something signified through an attempt at establishing it in embryo is of so singular a nature that it is rarely met with in the sphere of non-linguistic life' (Benjamin 2007 [1968]: 255). They seemed to all be spiraling around a strange 'vessel' (Harry Zohn's translation of Benjamin's «Gefäß»), a kind of vase or urn that looked like it had once been broken and put back together, but strangely, so that one could not quite get the shape or size of it - it seemed to change shape depending on the angle from which it was viewed. The embryo spirals were conjoined, winding and circling in-
Quand je mets en marche le machin, et que je vois que cela ne fonctionne pas, je suis obligée à ce moment-là d'en faire le tour pour voir ce qui déjante. Parfois il m'arrive de faire le tour et de voir que tout fonctionne bien. Mais quand je reviens, la pièce que je venais d'enclencher, et qui marchait parfaitement avant que je ne la quitte des yeux, a lâché. De la même manière que le «machin» de Planchat traduit le «what-do-youcall-it» de Russ, mais les deux ne font pas du tout référence à la même chose (Russ réfère à l'espace entre les univers, et Planchat au mécanisme qui permettrait le voyage entre les univers). Je le répare et normalement ça marche; et cela ne cesse jamais de m'étonner.

La technologie dans les univers de Russ s'emploie à l'aide d'un «casque à induction» (13), au lieu d'un machin, ce qui est peut-être la raison pour laquelle cela semble fonctionner plus correctement. J'aimerais bien m'en procurer un, mais il faudrait d'abord faire un saut à Lointemps. En effet, il faut peutêtre d'abord aller à Lointemps avant de pouvoir retrouver mon univers Slash, qui, jusqu'à présent, reste sans nom. Pour l'instant de toute manière, mon machin n'est pas capable d'assimiler les coordonnées des points de débarquement aux coordonnées des points d'arrivée. J'atterris toujours quelque part qui n'a rien à voir avec ce que je voulais.

Les coordonnées furent le produit de la racine queer de mes coordonnées dans le flux spatio-temporel, multiplié par la somme de toutes les théories des langues. Mais peut-être parce qu'elles sont toutes les deux paradoxales ou indénombrables (en transformation perpétuelle), une fois mes calculs saisis dans le machin, ce fut, au départ, comme le décrit Russ : ce qui m'entourait 'cess[ait] et recommen[çait] d'exister quarante mille fois par seconde.' (29). Mais au lieu de la matérialisation de 
between each other's swirls, but meeting finally at their base, just above the vessel. There, the two embryos joined together and dropped in.

What was in that vessel!? An intense desire seemed to form my soul, moving out from my body towards this question, and I continued flailing with much the same strategy I had employed in the folds of the robe (none), this time trying to move towards the center where the embryos joined and gained access to whatever mysterious and enviable (I'm not sure why I had this impression that whatever was in the vessel was enviable but I did) something or nothing lay within the vessel. As I moved closer to it, the embryos appeared to grow agitated for some reason I couldn't understand. I reached the entrance to the vessel at the same moment as two embryos, and the energy of their fusion cast me off, back into the gray might-have-been of the probability spread.

I saw many other worlds pass as I floated through the spread. And I realized that the space between languages was anything but thin, but was in fact incredibly vast, and many things were happening there. I was still flailing of course, beginning to believe this might help me: often, as you grow accustomed to something, you start inventing reasons for why it is the right way to do it. For a long while it did not help me to get a hold on any of the worlds, and they kept slipping by me until finally, in my desperate flailing I caught hold of the very tail end of a thread, or a kind of cord.

I soon had it in my two hands and was able to examine it. It seemed to quelque chose de nouveau devant mes yeux à sa place, je me retrouvai mêlée à du tissu très dense, très lourd - une sorte de manteau royal. Ce tissu me restreignait énormément, et j'étais comme prise dans un filet, me débattant à droite et à gauche, à la recherche d'une déchirure par où je pourrais sortir. J'étais bien consciente que cette agitation sans objet dans tous les sens ne m'aiderait pas à m'échapper, mais mon désir de fuir était tel que je ne pouvais m'en empêcher.

Après beaucoup de remous, je trouvai finalement la sortie et me dégageai des plis. Je n'y croyais pas mes yeux: deux spirales de germes flottants se prolongeaient loin audelà des limites de ma vision. «[C]ette représentation d'un signifié par l'essai, par le germe de sa création, est un mode de représentation tout à fait original, qui n'a guère d'équivalent dans le domaine de la vie non langagière»» (Benjamin 1971: 248). Ils paraissaient tous tourner en spirale autour d'un étrange vaisseau comme une «amphore» (dans la 1971 traduction de Gandillac), ou un «vase» (dans la traduction de Berman [2]), qui semblait avoir été cassé puis rassemblé, mais mal rassemblé !, d'une telle manière que la lueur d'une couleur qui ne ressemblait à aucune autre couleur sortait de ses brisures. Les spiraux de germes étaient imbriqués les uns dans les autres, leurs lignes se circulaient et se lovaient dans les tourbillons chevauchés, mais se joignaient enfin au fond, juste audessus du vaisseau. Là, les deux germes se rejoignirent enfin et tombèrent dans l'amphore.

Qu'y avait-il dans cette amphore!? Un immense désir s'éveilla en moi et forma une sorte d'essence, une vapeur, ou une odeur, presque, qui émana de mon corps, visa ce mystère, pendant que je continuai à me débattre dans tous les sens, 
be made out of a kind of code. Looking more closely the single unified thread of the code cord seemed to actually be woven out of many different strands, but working hard to present the impression of a single self-cohering cord. I followed it, winding it through my hands watching the fascinating colors of the different cords gleam and shimmy like an albacore shell. I followed it for what seemed like miles and miles until I saw a bright cube in the distance to which the cord was attached. I continued following the cord and entered into the machine.

The machine - not unlike the one that had sent me out into the 'great grey might-have-been' to begin with - was composed of many parts. But the difference was they did not seem to change when you looked away from them. Everything looked very tidy and orderly, and remained where it had been before you looked away. In the center was a giant vessel reminiscent of the one I had seen the embryos go into, except this contained a strange liquid resembling ink and sparking as though electrically charged. In the liquid was floating bits of garbage, both organic and manmade (rocks, bits of newspapers, computer and cell phone parts, plastic bags, body parts, but most of it unidentifiable). The liquid emitted an awesome sound, like the sound of a great chorus composed of voices both human in inhuman. The liquid was sucked up into hundreds of tiny tubes and fed into spinners where it was ground down, cooled, converted and shaped into the tiny threads that then went into the cord. But upon continued observation, I began to wonder whether the machine was producing the cord from the liquid, or whether the machine was powered by the cord, divided into tiny threads, and it was the threads that were actually producing the liquid. I tried to get closer to the vessel and the base of the tubes so that I could see whether adoptant la même stratégie (inexistante) que j'avais employée lorsque je m'étais retrouvée emprisonnée dans les plis du manteau, mais cette fois-ci en essayant de me diriger vers le centre où les germes s'étaient rejoints, pour accéder à quelconque mystère alléchant qui demeurait dans la vase (je ne sais pas d'où j'avais tiré l'impression que ce qui était dans le vase était attrayant, mais c'était le cas). Au fur et à mesure que je m'en approchais, les germes se mettaient à trembler et semblaient croître pour une raison je ne comprenais guère. J'atteignis l'entrée du vase au même moment que deux germes, et l'énergie produite à leur fusion me frappa et me renvoya loin vers les brouillards du grand possible.

J'apercevais beaucoup d'autres mondes passer alors que je flottais dans le possible. Et je me suis ainsi rendue compte que l'espace entre les langues était loin d'être comme une lame, aussi fine qu'une feuille de papier, mais que c'était, au contraire, une vaste étendue, habitée par un nombre incroyable de choses en devenir. Je me débattais toujours bien sûr, et j'avais presque perdu tout espoir de penser que cette action allait m'aider: souvent, lorsque l'on s'habitue à faire quelque chose d'une certaine façon, on commence à s'inventer des raisons qui nous rende certain de faire la bonne chose.

Pendant un long moment, ce mouvement ne m'aida pas à attraper le bout d'un des mondes qui filaient devant moi jusqu'au moment où, à l'achèvement d'un mouvement particulièrement énervé, j'attrapai la queue d'un fil, ou câble ou cordon.

Bientôt, je l'eu entre les mains et étais en mesure de l'examiner. Il semblait être fabriqué à partir de symboles, tous assemblés dans une sorte de chaînon. Après un examen plus détaillé, le cordon singulier et unifié résultait en réalité d'un tissage de beaucoup de fils différents, même s'il s'efforçait à paraitre comme un cordon unique, identique à lui- 
it was coming in or out. Honestly, it was impossible to tell, the liquid seemed to be moving in all directions at once. I peered closer and closer, until one half of my body was dangling into the vessel. I felt the same kind of sensation of overwhelming desire I had felt when approaching the first vessel. Before I knew it, I fell in and my body was mingling with that strange substance and I became part of the cord making up a third code (Baker 1998; Frawley 1984) from the materials of language.

The cord stretched on for a long time, long enough for me to lose my subjectivity. So I'll stop saying 'I' and start saying 'we', although the convention of pronouns in English or perhaps any language is not really apt to describe what 'we' are. We stretched on through the spread for ever and ever - although, as Russ mentions, even the spread is not totally infinite (154). And we finally came, as though tired, to rest upon a kind of planet, making a long line like a border across the land. It seemed to be a great dusty plain or a kind of desert. We formed a kind of 'dividing line, a narrow strip along a steep edge' (Anzaldúa 1987: 25). For many years we divided the land and for much of that time we remained in terrible pain, like an open wound ('una herida abierta'). Battles raged over us, armies stampeding over our delicate fibers, until we bled from the very real flesh of our fabric, from our tangled threads, the tidiness of our production totally disintegrated. This taught us that we were a feeling creature, and as a feeling creature we slowly, painfully and arduously healed, first ground down into nearly infinite (Russ 1975) particles of sand and rock and dirt. Then, from this soil, grew 'blades of grass pushing past the obstacles, sprouting on the même. Je suivis le lien en le passant entre mes doigts. Je regardai les couleurs fascinantes des fils qui luisaient et étincelaient comme l'on peut voir une ville luire la nuit depuis un avion. J'ai continué ainsi pendant ce qui paraissait être des kilomètres et des kilomètres, jusqu'à ce que j'aperçoive dans la distance une énorme boîte brillante à laquelle le cordon était attaché. Je décidai alors de continuer à suivre le cordon et pénétrai dans la boîte.

A l'intérieur, la boîte se révéla être une machine semblable à celle qui m'avait envoyée en premier aux larges des «brouillards du grand possible». Elle était composée comme l'autre de diverses pièces, mais la différence étant que ces pièces ne semblaient pas changer lorsque l'on en faisait le tour. Tout avait l'air bien rangé et bien ordonné, avec l'impression que tout resterait là où on l'avait placé, même si l'on devait détourner son regard ou partir en balade. Au centre se trouvait une cuve géante qui me faisait penser à celle où j'avais vu passer les germes, à l'exception près que celle-ci contenait un étrange liquide qui ressemblait à du pétrole, et qui émettait des étincelles comme si elle s'apprêtait à prendre feu. Dans le liquide flottaient des bouts de déchets, organiques et synthétiques (des cailloux, des fragments de tissu, du papier déchiré, des chaussures, des pièces mécaniques, des horloges, des livres ... mais la majorité n'étant même pas identifiable). Il émanait de ce liquide un son terrible, comme celui que l'on entendrait sortir d'un abattoir, où, à toutes heures, les animaux hurleraient pour que l'on mette fin à leurs souffrances. Le liquide était aspiré par des centaines de petits tubes et guidé dans des centrifugeuses où il était brassé, refroidi et recomposé pour former les mèches infimes qui, mises ensemble, formaient le cordon. Mais en examinant le procédé de plus près, j'en vins à me demander si c'était bien la machine qui alimentait le cordon, ou le cordon qui alimentait la machine. Celui-ci était 
page; the spirit of the words moving in the body is as concrete as flesh and as palpable; the hunger to create is as substantial as fingers and hand.' (Anzaldúa 1987: 98).

We grew and grew into massive trees. This was perhaps the most at peace we ever were, but - like all creatures with a history of suffering but - we had an inkling it would not last. And it didn't. We were chopped down and fed into a machine (a machine that brought back memories of our birth), to make sheets of paper. These sheets of paper were then fed into another machine which printed a black substance (recalling again, our birth) onto us, in intricate, repeating arabesques. The sheets, thus decorated were then pressed together, and covered with other sheets pressed together even tighter to make a thicker, protective paper. And so we were reconstituted into bound, square packages. They called us books, and together we made a library.

But this library was different from the ones found in your world:

Let us imagine a world, another world, that is a library... In this library where a post mortem Carmen is found, the travels are infinite and the combinations of volumes are never definitive. Carmen may spend two days in Meilhac and Halévy's libretto, and then go for a walk in Chaplin, stop for a rest in Mérimée, take a visit in Godard, come back to Berganza... In this library, books should never be put back in the same place, but moved around relentlessly in divisé en petits brins qui produisaient le liquide au fur et à mesure de leur dénouement, pour ainsi dire. Je tâchai de m'approcher de la cuve et des extrémités des tubes afin de voir si le liquide y entrait ou en sortait. Franchement, c'était tout bonnement impossible à distinguer; le liquide semblait bouger dans tous les sens, à la fois de haut et en bas et de droite à gauche. Je m'approchai de plus en plus, jusqu'à ce que les trois quarts de mon corps se retrouvent suspendus juste au-dessus du liquide qui résidait dans la cuve. J'étais comblée de désir comme lorsque je m'étais approchée du vase rempli de germes. Avant même de véritablement me rendre compte de ce qui était en train de se passer, je tombai dans la cuve et mon corps se trouvait mélangé à cette substance étrange. Après cela, je devins un tout avec le cordon et, ensemble, nous construisîmes un troisième code (Baker 1998; Frawley 1984) à partir du bric-à-brac langagier qui se trouvait dans la cuve.

Le cordon s'étira très loin, assez loin pour que j'eu le temps de perdre tout souvenir de mon corps. J'arrête alors de dire je, et commence à dire «nous» ou «on», même si les conventions pronominales en français, ou dans n'importe quelle langue sans doute ne sont pas sans doute tout à fait adaptées pour décrire ce que «nous» sommes. Nous nous étalâmes alors très loin dans l'étendu du possible, sans fin, infiniment ... même si, comme le dit Russ, l'étendu («spread», mot que ne traduit pas Planchat) n'est pas vraiment infini, juste très grand. Nous arrivâmes enfin, terriblement fatiguées, à nous (re)poser sur une sorte de planète. Nous dessinâmes alors une longue ligne, comme une espèce de frontière, sur un terrain qui ressemblait en quelque sorte à une grande steppe ou à un désert. Nous formions une «ligne de division, une bande étroite au long d'un bord précaire» (Anzaldúa 1987: 25, ma traduction). De longues années durant, nous divisâmes la terre et la 
unseen combinations. And if

Carmen is not happy with one version of herself (or another), she has all the more the power to transform the books since they cannot be fixed in place. (Rabau 2017: 64-65, my translation [3])

This description of the world we now found ourselves in takes Carmen as an example, but the same could be true for any character found in our books, and in any language. Indeed, writers, readers, translators, publishers and critics could interact as viscerally and corporeally with characters in the books as they would interact with each other. Another amazing feature of this interaction is that characters and readers, or readers and writers, or translators and characters (etc) did not have to speak the same language to one another. Conversations could frequently be overheard where one speaker was speaking French and another Arabic, or where two people were speaking Tagalog, one Navaho and one Swiss German ... you get the idea. But everyone seemed to more or less understand one another but or at least they seemed to understand one another to the same extent that speakers of one common language seem to understand one another, which is to say, very little indeed.

The sound of all these languages created a great sound, a 'stereoscopic' (Gaddis Rose 1997) sound very different from the one made by the primordial fluid of our birth, as it seemed to have a kind of structure to it instead of being just a great unidentifiable din. Or rather, it seemed to have a series of interweaving structures, even though these structures seemed always a bit out of reach, actively modulating, motivated by the very act of being heard. The stereoscopic melodies gave the feeling of a whole without ever presenting the totality of the whole to the listener.

The constant symphony of languages was indeed mimed performatively in majorité du temps, nous nous trouvions dans une immense douleur, comme une blessure ouverte («una herida abierta»). Les marchands marchèrent sur nous, les fugitives faufilèrent sur nos fibres délicates, jusqu'à ce que nous saignâmes de nos véritables veines qui couraient le long de nos véritables muscles, de nos fils entremêlés, le bon ordre de notre production se retrouvant totalement désintégré. Nous apprîmes ainsi que nous étions des êtres sensibles, et qu'en tant qu'être sensibles, nous allions guérir, lentement, laborieusement, douloureusement, mais pas sans avoir été d'abord écrabouillés en parties presque infimes, d'os et d'eau et de roches. Ensuite, de cette terre des «brins d'herbe pousseraient à travers les obstacles, croîtraient sur la page; l'esprit des mots qui se déplace dans le corps est concret comme de la chair et aussi palpable. La faim pour créer a autant de substance que les doigts et la main» (Anzladúa 1987: 98, my translation).

Nous grandissions, et nous grandissions, et ce jusqu'à ce que nous devînmes d'énormes arbres. Ce fut l'époque la plus tranquille de nos vies, mais but - comme tout être avec un passé empli de souffrances but - nous soupçonnions tout de même que cela n'allait pas durer. Et en effet, nous avions raison. Nous fûmes coupées et données à une machine (oui, encore une) pour faire de nous des feuilles de papier. Ces feuilles de papier furent ensuite données à une autre machine qui nous imprégnât à certains endroits d'une substance noire (rappel de naissance encore) sous la forme d'enjolivures délicates et sophistiquées. Les feuilles, ainsi décorées furent ensuite pressées toutes ensemble pour couvrir d'autres feuilles pressées, encore plus serrées pour créer un papier encore plus épais, plus menaçant. C'est alors que nous fûmes reconstituées en emballages carrés et reliées. On nous appela des livres, et mis ensemble, nous devinrent une bibliothèque. 
the architecture. I mean by performatively that the melodies themselves invented the architecture, which was constantly shifting, and growing. A whole discipline of mapmakers sprouted up, who treated the impossible and infinite character of their map-making with a kind of mystic reverence that somewhat annoyed the readers and characters, who were always bumping into them in the snaking hallways, called affectionately 'interliminals' (Gaddis Rose). About the architecture of the library, Marilyn Gaddis-Rose wrote, 'The work is a resilient axis in a circle or a globe with a circumference that wavers and shifts - both horizontally and vertically. But what that infinitely expanding and contracting circumference contains belongs to the axis and is part of the work's potential' (Gaddis Rose 1997: 7).

The readings and reflections that happened in the library thus created new texts, and new beings. Again, Gaddis Rose on the library: 'What we shall achieve if we complete the tale is a collaborative, if only partially articulated, text of our own.' (29). In one allegory, she tells about the meeting between two languages in the particular articulation of three texts, in which the meeting of the different systems of gendering in-between two languages creates a kind of third text in the interliminal space (remember, in the library, the voyages of languages create real architecture): 'It is translation and the interliminal space' (italics in the text) 'that makes readers even notice gender and consider it an issue' (69).

In the same way that the library is not simply a record of stories carefully laid down, but actually creates stories, it also creates subjects: characters, readers, translators... The architecture of these subjects, is not stable and fixed, but mobile, like the library in which they live.
Mais cette bibliothèque était différente de celles de votre monde:

Imaginons un monde, un autre monde, que soit une bibliothèque... Dans cette bibliothèque où se retrouve Carmen post mortem, les trajets sont infinis et les combinaisons de volumes jamais définitives. Carmen peut passer deux jours dans le livret de Meilhac et Halévy, puis faire un tour chez Chaplin, se reposer chez Mérimée, aller voir du côté de Godard, revenir à Berganza; dans cette bibliothèque, il ne faut jamais remettre les livres en place, mais les déplacer sans trêve en des combinaisons inédites; et si Carmen n'est pas contente d'une version de soi (ou d'une autre), elle a le pouvoir de transformer les livres plus qui ne peuvent la figer. (Rabau 2017: 64-65)

Cette description du monde, dans lequel nous nous trouvions enfin, prend Carmen comme exemple, mais la même chose pourrait être dite de n'importe quel personnage que l'on retrouve dans nos livres, et ce dans n'importe quelle langue. En outre, les écrivaines, les lectrices, les traductrices, les éditrices et les critiques peuvent fréquenter ces personnages de manière aussi vive et charnelle qu'ils ne se fréquenteraient eux-mêmes. Une autre facette passionnante de cette interaction était que les personnages et les lectrices, ou les lectrices et les écrivaines, ou les traductrices et les personnages (etc) ne devaient pas forcément parler la même langue pour se comprendre. Fréquemment, on entendait des conversations dans lesquelles un locuteur arabophone discutait avec un autre qui parlait bengali, ou encore dans lesquelles deux personnes parlaient quechua, un autre finnois et un autre wolof ... vous aurez compris. Mais tout le monde semblait plus ou moins se comprendre - ou au moins ils 
Another strange feature of the library were the staircases, which were stacked on top of one another, unwieldy like a too tall tower of file folders. The top sides and the undersides of the stairs were made out of mirrors, and so above you appeared the staircase below you and below you, the staircase above you. This was not the strangest thing however. The mirrors reflected in a very odd way: the viewer was never represented in the mirror, but only their reflection. In other words, the mirror image of the viewer in the above or below mirror (the opposite of wherever they happened to be looking) was reflected off into infinity. But there was no first reflection, almost as though the world the viewer was standing on were paradoxically representable: representable yet not directly to itself.

As I looked more closely (I say I because I had become one again in the library), I could see that it was not a reflection at all but a kind of slow mutation stretching back through the mirrors, so that when I squinted very hard I could see the infinitely varying process of a person being created or creating themself, who was not similar to myself in any way, although no detectable differences could be seen from one person reflected in the mirror to the next. I realized then that I was no longer in the library but rather in a kind of third space, «Third Space, through unrepresentable in itself ... constitutes the discursive conditions of enunciation that ensure that the meaning and symbols of culture have no primordial unity or fixity; that even the same signs can be appropriated, translated, rehistoricized and read anew» (Bhabha 1989: 37). Somehow I was no longer the person on the stairs but the incalculable set of persons evolving through the process of reflection from one mirror to the next. semblaient se comprendre autant que les locuteurs d'une même langue se comprennent, c'est-à-dire pas très bien, en réalité.

Le son de toutes ces langues créa un vacarme étourdissant, un son «stéréoscopique» (Gaddis Rose 1997), qui semblait être quelque peu structuré, contrairement à la cacophonie assourdissante qu'avait produit le fluide essentiel à notre naissance. Ou plutôt, ce nouveau vacarme semblait être composé d'une série de structures qui se chevauchaient, même si elles étaient insaisissables, comme si le fait même d'être entendues déclenchait en elles l'activité du transfert. Les mélodies stéréoscopique donnèrent à l'auditrice le sentiment d'un tout sans jamais en présenter la totalité.

La symphonie continuelle des langues fut en effet imitée dans l'architecture de la bibliothèque de manière performative. J'entends par là que les molécules elles-mêmes inventaient l'architecture, dont les éléments ne cessaient d'apparaître et de disparaître. Une discipline entière de cartographie s'annonçait, dont l'étude du caractère paradoxal et potentiel du plan de la bibliothèque inspirait une sorte de piété mystique qui ne manquait pas de vexer les lectrices et les personnages qui se heurtaient continuellement aux cartographes; engloutis dans leurs tâche, sans se soucier de l'autre qu'ils surnommaient avec amour les «interliminales» (Gaddis Rose). Au sujet de l'architecture de la bibliothèque, Marilyn Gaddis Rose écrit: «L'œuvre est un axe résilient en forme de cercle ou de globe avec une circonférence qui oscille et qui bouge - à la fois horizontalement et verticalement. Mais ce qu'elle contient, cette circonférence en augmentation et en contraction continue, appartient à l'axe et fait partie de la potentialité de l'œuvre.» (Gaddis Rose 1997: 7, ma traduction).

Les lectures et les réflexions qui prenaient place dans la bibliothèque 
This, indeed, is not unlike Russ's description of probability mechanics itself, in which possibility strands are perpetually splitting into separate time lines, unique arrangements of molecules like snowflakes. So then, in a way, all beings in all timelines inhabit a third space, trailed by an infinite constellation of possible selves.

For a long time, my other selves which was myself (since we were all other selves of each other, there was no one or selfsame self anywhere to be found) were content just to stand around, loitering in third space as it were. But then someone had an idea to make a gesture. Another one found it amusing to imitate this gesture. From one end of the line to the other, the gesture was repeated so that the gestures made on either end of the line did not resemble each other at all, like a game of telephone, but in the form of a dance. Over a great deal of time, this gave rise to a great deal of gesticulating, and eventually, discussion, such that the line was divided. This division centered around a disagreement about the formation of the gesture in the line. The disagreement did not oppose one gesture to the other as you might think, since how could you locate the point at which the two separated from one another? Rather, there were several camps (in each camp were people from different areas of the line): those who believed that there were indeed two gestures at either end of the line, two gesture 'poles' as it were; those who believed there was just one gesture with infinite variations; those who believed there were several 'types' of gestures and tried to classify them; those who believed the gesture had no end and no beginning and could therefore not be defined as one or as many ... you get the idea. finirent par créer de nouveaux textes, et de nouveaux êtres. Gaddis Rose ajoute au sujet de la bibliothèque: «Ce à quoi on arrive lorsqu' on termine ce conte est notre propre texte collaboratif même s'il n'est articulé qu'en partie» (29, ma traduction). Dans une allégorie, elle raconte la rencontre entre deux langues dans leur déploiement particulier à travers trois textes, dans lesquels le conflit entre les deux systèmes grammaticaux crée une sorte de texte tierce [9] dans l'espace interliminal: «C'est la traduction et l'espace interliminal » (italiques dans le texte) «qui fait que les lecteurs se rendent compte du genre et en font une problématique» (69, ma traduction).

De la même façon que la bibliothèque n'est pas simplement une archive d'histoires soigneusement posées sur le papier, elle crée les histoires : les personnages, les lectrices, les traductrices... L'architecture de ces sujets ne sont ni fixes ni stables, mais mobiles, comme la bibliothèque dans laquelle ils vivent.

Une autre dimension, plutôt drôle cette fois, de cette bibliothèque avait lien aux escaliers. Ces derniers furent entassés les uns sur les autres en couches, comme un tas de pierres. Les dessous et les dessus des escaliers furent fabriqués avec des miroirs, de telle façon que l'on voyait sur le sol l'escalier au plafond et sur le plafond l'escalier au sol. Mais ce n'était même pas le plus étrange. L'effet de réflexion des miroirs était des plus étranges. En effet, la spectatrice ne se voyait jamais elle-même représentée dans le miroir; elle ne parvenait à voir que son reflet. Autrement dit, le reflet de la spectatrice en haut ou en bas du miroir (le contraire de là où elle regardait) se répétait à l'infini. Mais il n'y eut jamais de premier reflet, presque comme si le monde habité par le spectateur ne pouvait se représenter que paradoxalement, représenter mais pas représenter soimême. 
This is when I realized that I was writing this very text you are reading now - or some version of it. And that I had in fact all along been inventing the Slash universe I was seeking to find: that trying to find or invent the universe and not being able to was in fact synonymous with its invention, or its discovery. This confusion probably explains my difficult finding a name, so let's just use [xxx] as a placeholder. [Xxx] is an allegory, meaning as it mimes, it deforms, translating meaning into new form. As such, $[\mathrm{xxx}]$ is constantly [xxx]ed and re[xxx]ed, never staying still.

$[\mathrm{Xxx}]$ then is not so much a place, as an operation or a game. This is what I have elsewhere called the 'épochè queere' [4] - a reading operation existing at the mobile dividing lines between translations (texts and languages), in which theft and deformation are permittable (no respect for the original), and in which each figural act, too swiftly to count the seconds, reads itself, doubles, rewrites or translates itself, becomes an allegory of its own allegorization.

If I say that travel between Russ' potential universes is the space in which [xxx] would operate, I am saying this allegorically: the 'twisted braid' of alternatives upon which we live, should somehow make a show for certain characteristics of queerness that I do not wish to or cannot express without invoking metaphor. Some might say that to make metaphor is to operate in the realm of essences: either invoking preexisting essences or making them anew in the performance of metaphor. The risk here is that these essences fix a universe, and the universe of $[\mathrm{xxx}]$ cannot be fixed, since it is motion itself, the constant 'blurring from one to the other without even knowing it.' The moment then that we speak of $[\mathrm{xxx}]$ we annihilate it.
Lorsque je regardai plus en détail (je dis je parce que je suis redevenue un moi dans la bibliothèque), je pouvais voir que ce n'était absolument pas un reflet au final, mais une sorte de métamorphose très lente, qui remontait par les miroirs, de telle sorte que quand je plissai les yeux très intensément je pus voir un processus en variation continue; comme si je voyais les photogrammes individuels d'un film où le personnage se métamorphosait en quelqu'un d'autre. A la fin, je vis un corps qui n'était pas du tout similaire au mien, même si aucune différence ne pouvait être notée entre deux personnes dans cette chaîne de reflets. Je me rendis compte alors, que je n'étais plus dans la bibliothèque mais que j'étais dans une sorte d'espace autre: «C'est ce tiers-espace qui, bien qu'irreprésentable en soi, constitue les conditions discursives d'énonciation assurant que la signification et les symboles de la culture n'ont pas d'unité ou de fixité primordiale; qu'il est possible de s'approprier jusqu'aux signes mêmes, de les traduire, de les réhistoriciser et d'en faire une nouvelle lecture» (Bhabha 2007: 82). Je réalisai que, par le paradoxe de la traduction, je n'étais plus la personne sur les escaliers, mais une série incalculable de personnes en évolution à travers le processus de réflexion entre un miroir et la prochaine.

Finalement, on se rend compte que cette description n'est pas bien loin de la description que Russ fait de la mécanique de probabilité, dans laquelle les brins ou les mèches ou les fils ou les câbles ou les cordons sont perpétuellement en train de se diviser en chronologies diverses, en constellations aussi uniques que des flocons de neiges. A certains égards, tous les êtres que l'on retrouve dans toutes les chronologies habitent une sorte de troisième espace, et existent au travers d'une infinie possibilité d'identités, possibles. 
inhabiting the in-between movement between alternative universes, multiplying too quickly to pin down, would itself have to move - hop! as quickly as the universe it seeks to represent. The moment you think you've got an idea of [xxx], it changes -

So then, perhaps a better question would be: is [xxx] not uninhabitable? Or rather, can it be escaped? Can it be differentiated from other worlds enough so that one might live in it and not in another? Because if [xxx] is all, and all is [xxx], can universes be told one from the other at all? Haven't we just created something like an invisible Empire, a dictatorial teleology, erasing differences, parading under some new, falsely utopian name? And aren't I, as creator of this universe, just dressing up my privileged white feminism in new clothes, proposing the name of a 'better' alternative universe, without asking anyone's opinion on the matter?

It seems I've come to an impasse in which my dream of making everything mobile has fixed the whole of everything in a ceaselessly mobile realm, of which I am the sad Queen who failed to find escape from the totalizing gesture. It is here that I would like to set down my crown, usher in rebellion, and take a nap with les chattes [5].

As I wander off into the everyday probable universe of dreams, I am reminded that paradoxically, we continue to live together and make worlds such as our own or such as Whileaway - although I still don't know how this is possible. How can we believe to share one universe that is composed of constantly proliferating multiple universes? How can bodies retain their difference, and essences be transformed, when bodies and essences are inseparable? How can porous bodies appear so distinct?
Pendant longtemps les autres - qui furent moi en fin de compte (puisque nous étions chacun l'autre soi des autres, il n'y avait pas d'unique ou de soi solitaire) furent heureuses tout simplement en errant ainsi dans cet espace-tiers, sans aucun rendez-vous ou obligation ou tâche à remplir. Mais finalement, quelqu'un eut l'idée de faire un geste. Et un autre trouva cela hilarant de reproduire ce geste et ainsi de suite. D'un bout de la ligne à l'autre, le geste fut imité tel que celui d'une extrémité ne ressemblait en rien à celui de l'autre extrémité, comme le jeu du téléphone arabe, en forme de chorographie. Au bout d'un moment, elle donna suite à un énorme festival de gesticulation, ou autrement dit, une discussion, et la ligne fut divisée. Le désaccord n'opposa pas un geste à un autre comme vous auriez peut-être pu l'imaginer. Comment aurait-on pu localiser le point la différence s'opéra? Cela aurait été impossible. A la place, il y eut plusieurs camps (dans chaque camp se retrouvèrent des gens qui venaient de diverses parties de la ligne): ceux qui croyaient qu'il y avait juste un geste aux variations infinies; ceux qui pensaient qu'il y avait plusieurs «types» de gestes et qui essayaient donc de les classifier; ceux qui étaient persuadé que le geste n'avait ni début ni fin, et donc ne pouvait finalement pas être défini comme un seul ou comme plusieurs ... vous aurez compris.

C'est à ce moment-là alors que je me suis rendue compte que j'étais en train d'écrire le texte que vous êtes actuellement, en ce moment présent, en train de lire - ou une quelconque autre version. Et, qu'en fait, j'avais, tout du long, été en train d'inventer l'univers Slash que je cherchais à créer. J'ignorais quel nom lui donner, donc j'écrivais [xxx] juste pour occuper la place. [Xxx] est donc une allégorie, c'est à dire qu'elle mime, elle interprète et traduit les formes de significations pour les donner à de nouvelles formes. Ainsi, [xxx] est 
How is it possible for queerness to be everywhere in a world that repudiates it?

I will leave now, the invention of [xxx], to you. $[\mathrm{xxx}]$ ifiée et ré[xxx]ifiée en permanence. Elle ne reste jamais immobile.

[Xxx] est donc moins un lieu qu'une pratique ou un jeu. Elle serait similaire à ce que j'ai appelé à d'autres moments l' «épochè queere» [4] - une manipulation de lecture qui existe à la frontière mouvante qui existe entre les traductions, et où l'on vole. J'entends le mot «vol» dans le sens de Cixous (1975) ici, comme ce que fait l'oiseau, la voleuse, et la femme.

Si je propose que voyager entre les univers potentiels de Russ est l'espace même où se retrouve [xxx], je le dirais d'une manière allégorique: cette «tresse entortillée» (19) de multiples univers dont on fait partie, devrait montrer d'une certaine façon, les qualités du queer auxquelles je ne souhaite pas renoncer ou que je ne peux pas exprimer sans faire, encore une fois, de nouvelles métaphores. Le risque ici est que ces essences se fixent et immobilisent l'univers, et [xxx] est un univers qui ne peut pas s'immobiliser, "glissant puisque nous restons dans les limites d'un ensemble de variations qui pour nous ne font aucune différence.» $\mathrm{La}$ traduction entre l'anglais et le français ici nous démontre bien le jeu, en traduisant le savoir par la différence: il faut bien différer son savoir pour savoir. Dès le moment où l'on commence à parler de $[\mathrm{xxx}]$, on l'anéanti.

Une métaphore adaptée à [xxx] alors, doit aussi adapter, se déplacer, traduire et se traduire, trop vite pour la localiser. Et au moment où les termes se fixent, ils sont tout de suite troublés, changent de lieu, se décrochent du pied du mur, aussi vite que l'univers qu'il cherche à représenter. Le moment où l'on pense l'avoir capturé $[\mathrm{xxx}]$ -

Alors, une meilleure question serait peut-être: $[\mathrm{xxx}]$ n'est-elle pas inhabitable? Ou bien, peut-on 
s'échapper d' $[\mathrm{xxx}]$ ? Se différencie-telle d'autres mondes suffisamment pour que l'on puisse vivre dans un monde au lieu d'un autre? Car si $[\mathrm{xxx}]$ est tout et tout est $[\mathrm{xxx}]$, comment reconnaître la différence entre les univers? Ne serait-il pas que l'on vient d'inventer quelque chose comme un Empire invisible, une téléologie dictatoriale, qui efface toutes les différences, défilant sous le mode d'un nouveau nom, faussement utopique? Et moi, ne suis-je pas, en tant qu'inventrice de cet univers, tout simplement en train de déguiser mon féminisme blanc et privilégié dans de nouveaux termes, au nom d'un «meilleur» univers alternatif, sans poser la question aux gens qui, j'imagine, y vivraient réellement?

Il me semble que je suis arrivée dans une impasse, au bout de laquelle mon rêve de tout mobiliser, a finalement fixé le tout dans un domaine de mouvement perpétuel et dont je suis la triste Reine, qui n'a pas réussi à trouver de sortie à son geste totalitaire. Je voudrais désormais renoncer à ma couronne pour laisser la révolution s'installer à ma place, et faire une sieste avec les chattes.

Lorsque je m'égare vers cet univers potentiel et quotidien qui est celui des rêves, un paradoxe m'est ainsi rappelé: celui que, malgré tout, nous continuons à vivre ensemble et à faire les mondes tels quel les nôtres et tels que Lointemps - même si je ne sais toujours pas comment cela pourrait être possible. Comment chaque corps pourrait-il être totalement singulier, mais aussi traduisible en même temps? Comment arrive-t-on à se comprendre? Arrive-t-on à se comprendre? Faut-il comprendre?

Alors, quelle forme prendrait cet univers $[\mathrm{xxx}]$ ? A vous de jouer. 
[1] Slash fiction is a sub-genre of fan-fiction, devoted to queer narratives. It plays an important role in Russ's critical work (cf Russ 1985). return to text

[2] Berman's translations of Benjamin can be found in: Antoine Berman, L'Age de la Traduction: «La tâche du traducteur» de Walter Benjamin, un commentaire (Berman 2008). return to text

[3] [Author's note: I have seen a pre-publication version of this work.] return to text

[4] «Third text» or «Tiers texte», as well as the term «épochè queere» are subjects I develop in my doctoral dissertation (Robert-Foley 2014). return to text

[5] www.meduusa.fr (accessed 13 December 2014). [Author's note: The Meduusa site is down, sadly. I don't know when it will be back up again] return to text

\section{Works Cited}

Anzaldúa, G 1987 Borderlands: the new mestiza = La frontera, Spinsters/Aunt Lute, San Francisco return to text

Baker, M 1998 'Réexplorer la langue de la traduction: une approche par corpus', Meta: journal des traducteurs/Meta: Translators' Journal 43, 4: 480-485 return to text

Benjamin, W 1971 'La tâche du traducteur', Mythes et Violence, trans M Gandillac, Denoël, Paris: 261-75 return to text

Benjamin, W 2007 [1968] 'The task of the Translator', Illuminations, H Zohn (trans), Schoken Books, New York: 62-82 return to text

Berman A 2008 L'Age de la Traduction: «La tâche du traducteur» de Walter Benjamin, un commentaire, Presses universitaires de Vincennes, Saint-Denis return to text

Bhabha HK 1989 The Location of Culture, Routledge, New York return to text

Bhabha HK 2007 Les Lieux de la culture. Une théorie postcoloniale, trans F Bouillot, Payot, Paris return to text

Cixous, H 2010 [1975] Le Rire de la Méduse, Galilée, Paris return to text

Dryden, T 1961a [1680] 'On Translation', Essays of John Dryden, vols. 1 \& 2, Russel, New York return to text

Dryden, T 1961b [1680] 'John Dryden's Preface to Ovid's Epistles (1680)', trans M-A Belle, Projet Textes Théoriques sur la Traduction, Université Paris 3 - Sorbonne Nouvelle, Paris: ttt.univ-paris3.fr/spip.php (accessed 12 December 2015) return to text

Frawley W 1984 'Prolegomenon to a Theory of Translation', in W Frawley (ed) Translation: Literary, Linguistic, and Philosophical Perspectives, Associated University Presses, London \& Toronto: $159-175$ return to text

Gaddis Rose, M 1997 Translation and literary criticism: translation as analysis, St Jerome, Manchester return to text

Humboldt, W 1992 [1816] 'From the Introduction to His Translations of Agammenon', Theories of Translation: An Anthology of Essays from Dryden to Derrida, trans S Sloan, University of Chicago Press, Chicago IL: 55-59 return to text

Lacayo, A 2014 'A Queer and Embodied Translation: Ethics of Difference and Erotics of Distance', Comparative Literature Studies 51, 2: 215-230 return to text

Lotbinière-Harwood S 1991 Re-belle et infidèle: la traduction comme réecriture au feminine / The Body Bilingual: translation as rewriting in the feminine, Les Editions du remueménage/Women's Press, Québec return to text

Rabau, S 2017 Carmen, pour changer: variations sur une nouvelle de Prosper Mérimée, Anacharsis, Paris return to text 
Robert-Foley, L 2014 Politique et Poétique du Tiers Texte: Une expérience de lecture de L'Innommable/The Unnamable de Samuel Beckett, Thése de doctorat, Université Paris, SaintDenis return to text

Russ, J 2011 [1975] The Female Man, Beacon Press, Boston return to text

Russ J 1985 'Pornography by Women for Women, With Love', Magic, Mommas, Trembling Sisters, Puritans and Perverts: Feminist Essays, Crossing Press, Trumansburg NY return to text

Russ, J 1977 L'Autre moitié de l'homme, trans HL Planchat, R Laffont, Paris return to text

Schleiermacher, F 1992 [1813] 'from On the Different Methods of Translating', Theories of Translation: An Anthology of Essays from Dryden to Derrida, trans Waltraud Barscht, University of Chicago Press, Chicago IL: 36-54 return to text

Lily Robert-Foley is the author of Jiji, a love story of coded prose poems (Omnia Vanitas Press, 2016); 'Money, Math and Measure' (Essay Press digital chapbook series, 2016); m, a book of poetry-critique-collage (Corrupt Press, 2013); graphemachine, a chapbook of visual poetry (Xerolage, 2013); the creative annotations for The North Georgia Gazette (Green Lantern Press 2009). She is an Assistant Professor in English specialiazing in Translation at the Université Paul Valéry, Montpellier 3. She performs internationally digital imprints into city walls.

TEXT

Vol 20 No 2 October 2016

http://www.textjournal.com.au

General Editor: Nigel Krauth. Editors: Kevin Brophy \& Enza Gandolfo

text@textjournal.com.au 